\title{
興津における近代の別荘の形成とその背景 DEVELOPMENT PROCESS AND THE BACKGROUND OF VILLAS OF MODERN AGES IN OKITSU
}

\author{
土屋和 男*
}

Kazuo TSUCHIYA

\begin{abstract}
Okitsu was a place suitable for retreat villa area between the end of the 19th century and the second world war. Famous person's villa was built in Okitsu, and an excellent villa area was formed. Okitsu was located in the far from Tokyo in the beach villa area formed along Toukaido Line. There were not a lot of numbers of villas in the small scale. Therefore, owners had a personal connection. In this text, the villa made in Okitsu is researched. The historical background of Okitsu and the connection of owners are clarified. This is connected with knowing what place was ideal for famous persons.
\end{abstract}

Keywords: Okitsu, Villa and Cottage, Modern Japanese Style, Scenic area, Place and Location

興津, 別荘, 近代和風, 景勝地, 場所性

\section{1.はじめに}

静岡市清水区興津地区は、明治中期から昭和戦前期にかけて著名 人の別乼が建てられ、良好な別荘地が形成されていた。興津は、近 代において東海道線沿いに形成された海浜別荘地のなかでもっとも 西に位置し、東京から遠い別荘地であった。小規模で別荘の数は多 くはなかったが、その建筑主には井上馨や西園寺公望をはじめとし て、政治・経済上きわめて重要な人物たちがいた。建築主たちは特 に老人の場合、鿵棲や避寒を目的とし、小規模であるがゆえに互い に何らかの人間関係があるような間柄であった。

一般に、別荘造営にあたっては建築主個人が娛しみや保養を目的 とし、自らすすんで場所を選び住宅の様式を決めるので、建築主の 趣味が反映しやすい。とりわけ土地の限られた小規模な場所におい ては、建築主たちは同じ場所に対する指向を共有する者たちとして 考えることができる。

本稿では、町史、伝記等の史料と現地におけるヒアリングに基づ いて、興津においてつくられた別荘を概観するとともに、興津がど のような歴史的背景をもち、どのような建築主たちのつながりによ って、別荘地が形成されていったのかを考察する。このことは、当 時の要職にあった建筑主たちが、自らの娛しみのためのすまいにど のような場所を理想としていたのかを知ることにつながり、それは
また、当時のすまいの理想型の一端を知ることにつながると考えら れる。

近代の別荘地形成に関して、本稿と地域的に関連する研究として は、十代田朗氏、渡辺貴介氏、安島博幸氏らによる関東圈における 別荘の立地とその類型に関する包括的な研究があり、一部興津に関 しても触れられている ${ }^{1)}$ 。小沢朝江氏、水沼淑子氏には東海道線沿 いの皇族別荘を报った研究がある ${ }^{2)}$ 。建築主たちの趣味や階層の点 で関連する研究としては、矢ヶ崎善太郎氏による京都東山の別荘地 形成に関する一連の研究があり ${ }^{3)}$ 、同地域を景観形成史的にとらえ た出村嘉史氏、川崎雅史氏による研究もある ${ }^{4)}$ 。なお、筆者は興津 における別荘地形成に関する研究として、これまで個々の事例につ いて数度にわたって発表を行っている5)

\section{2. 別荘形成までの前史 2-1.地勢と自然景観}

興津において別荘地が形成されていた地区は、東西約 $3 \mathrm{~km}$ 、南北 は海と山に挟まれた数百而の細長い地区である。ここを東海道と鉄 道の東海道線が貫いている。

地区の周囲は、東側が薩垂峠でこの歰越しに富士山の山頂が眺め られる。西側は江尻（現在の静岡市清水区の中心部）に向かって開 
けているが、海岸線は南に向かって湾曲し、さらに三保地区が囲い 込んで清水港を形成する。清水港は駿河湾の一部だが、興津地区の 南側の景観は、港内の海越しに三保地区の砂嘴を望み、さらにその 背景に広い駿河湾が拡がるものとなる。三保地区の砂嘴に自生する 松が三保の松原である。清水港内の興津地区の海岸は、昭和 40 年代 に埠頭建設のために臨海が埋立られるまでは、浅い岩場で潮の干満 によって岩が見え隱れし典型的な潟の景観を得られる場所として知 られていた。これを清見潟（きよみがた）と呼んだ ${ }^{6)}$ 。らに、南 東の海上には伊豆の山々が連なる。富士山を前景となる山越しに背 負い、海上には岩を配し、松原を浮かべ、遠く山々を連ねるという 自然景観は、次に述べるように景勝地として知られることとなった。 北側は山が迫っており、このため冬季には柑霹類の栽培に適する ような、きわめて温暖な気候が得られる。

\section{2-2.前近代までの前史 \\ (1)清見寺の存在}

興津は東に峠を控え、海と山が非常に接近した地形で、東海道と、 北に向かって興津川沿いに身延をとおり甲府に至る街道の結節点で もあり、古くから交通の要衝であった。古代には東国への関所とし て清見が関（きよタがせき）が開かれ、この関所に付属する寺とし て清見寺（せいけんじ）がつくられた。清見寺は戦国時代に今川氏 の台頭とともに復活し、徳川家康が幼年期に預けられたり、豊臣秀 吉が北条氏征伐のための拠点とし、秀吉に会いに千利休が訪れるな どしている。江戸時代には徳川幕府の庇護を受け、その知名度は強 力なものとなる。興津は江戸時代には東海道五十三次の宿場となっ たか゚、朝鮮通信使、琉球使節の宿泊、休息には本陣ではなく清見寺 が用いられた。清見寺は山の中腹に海を望んで建ち、その伽藍は自 然景観との複合的景観としてよく知られていた。

\section{(2)古典的名所}

上述のような景観と史実から、興津は近代以前から伝統的に文学、 絵画において景勝地として取り上げられてきた。和歌においては 「きよみがせき、きよ夕がた」「たごのうら」 ${ }^{7)}$ の歌枕で詠まれた。 歌枕となる名所として位置付けられると名所絵が作成され、また山 水画の画題ともなった。なかでも、伝雪舟筆「富士三保清見寺図」 は、興津の対岸の山（現在日本平と呼ばれている場所）からの景観 に基づくもので、この構図は江戸時代に狩野派によって継承され、 江戸城の障壁画にもなっていた記録がある ${ }^{8)}$ 。さらに、江戸時代に は文人による紀行文 ${ }^{9)}$ や朝鮮通信使による漢詩 ${ }^{10)}$ などが残された。 これらを通して浮世絵や名所図絵など、より広範な文学、絵画の題 材ともなり、興津の景観は古典的な名所として巷間に流布していた のである。

\section{2-3.近代における前史}

\section{(1)皇太子の海水浴場}

近代以降、興津の場所を性格付けたのは皇太子 ${ }^{11)}$ (後の大正天皇) の海水浴場としてであった ${ }^{12)}$ 。1889 (明治22) 年、東海道本線が開 通し興津駅が開設された。その夏、皇太子は3週間を興津で過ごし、 海水浴をしたと記録されている ${ }^{13)}$ 。皇太子は翌年にも同じように海 水浴に訪れた。全国でも海水浴がはじまってからわずか数年のきわ めて早い時期のことである。皇太子の滞在には清見寺が用いられた。
なお、清見寺は1869（明治2）年および1878（明治11）年の明治天 皇御巡幸時の休息所ともなっており、鉄道開通までの間も前近代以 来の特別な休息所としての役割を果たしていた。この蓄積の上に皇 太子の行啓先が決められたと推測される。

明治中期以降の興津には皇太子のほかにも、皇后をはじめとした 多数の皇族が保盖を目的に行啓している。行啓先は清見寺が多かっ たが、後述するように井上邸や川崎邸などの別荘にも行憵している。

\section{(2)水口屋の存在}

東海道線の開通と皇太子の海水浴の前後から、海水楼、東海ホテ ルなどの宿泊施設がつくられ、これらには多くの著名人が泊まった との記録がある ${ }^{14)}$

最も古く、かつ重要な旅館は水口屋で、もともと江戸時代には脇 本陣であったものが明治以降宿泊施設として経営された。1879（明 治12）年、岩倉具視は水口屋が焼失した際に見舞を置いている ${ }^{15)}$ 同年再建された水口屋はこれ以降、東海道を通行する貴顕たちの宿 泊所となり、別荘地時代の建築主たちが興津を知るきっかけになっ たと推測される。水口屋が所蔵していた書だけでも、伊藤博文、山 縣有朋らの揮毫になるものがある。さらに水口屋は勝間別荘という 貸別荘も営んでいた。西園寺公望は別荘・坐漁荘を営む前にこの貸 別荘に数度にわたり滞在し ${ }^{16)}$ 、坐漁荘の敷地も水口屋当主望月半十 郎から取得したという ${ }^{17)}$ 。後述する阿部䄮から検出した棟札にも 「總世話方」として望月保太郎の名が見られる。これらから水口屋当 主は別荘敷地等の翰旋を請け負い、興津における別荘形成に重要な 役割を果たしていたとみられる。別荘ができると、水口屋は別荘へ 料理を調達したり、客の宿泊所となった。

\section{3.別荘の形成}

\section{3-1.蕃名人の別在}

興津につくられた別荘で、町史、伝記等の史料と現地におけるヒ アリングや目視によって、立地や建設年が確認できるのは6件である 18（ほかに史料中にのみ記述があり場所が確認できないものが2件あ る)。表1および図1に示す。現存する遺構はわずかで、著名人の別荘 では旧阿部正桓䄮が荒廃した状態で、旧大蔵和親邸が改装された状 態で残る。以下、項目ごとに別荘地としての興津の形成を見る。

\section{(1)建設年}

興津における別荘は、1896（明治29）年頃 ${ }^{19)}$ に井上謷が、地区の 西端、隣接する横砂地区と興津地区とにまたがって、広大な敷地を 取得したことに始まっている。その後の著名人による別荘の造営は 以下のように続く（( ）内は当時の建筑主の役職等)。

1896 (明治29）年頃 井上秚邸（前内務大臣、伯爵）

1899 (明治32) 年 阿部正桓邸（元福山藩主、東京の大土 地所有者 (西片町)、伯爵)

1907 (明治40) 年 川崎正藏邸（川崎造船創業者、男爵）

1910 (明治43）年 大倉和親㿟 (日本陶器社長)

1918（大正7）年伊藤博邦邱・独楽荘（宮内省式部長官、 公爵）

1920 （大正9）年西園寺公望邸・坐漁荘（元総理大臣、 侯㩱、元老）

興津における別荘の建設年は、明治30年頃から大正前半期にかけ てと、湘南、熱海、沼津等、他の東海道線沿いの海浜別荘地別荘地 
と比べて短い。鉄道による移動で別荘建設が可能になってから比較 的初期に形成され、その後の開発が進まなかった地域といえる。こ のことは地区の土地が限られていたこと、別荘の所有者に高位の役 職に就く老人がいたこととも関係があるものと思われる。

\section{(2)立地と票地の樣子}

立地は2つのタイプに大別できる。すなわち、小高い山に位置し海 と街を眼下に見るタイプと、海岸沿いに位置し海に隣接するタイプ である。前者に属するのは、井上期、阿部邸、伊藤邸であり、後者 に属するのは川崎邸、大倉邸、西園寺邸である。

井上邸は「約5万坪」とか「約十七町歩」と伝えられ ${ }^{20}$ 、他と比べ て広大で、波多打川の谷之両側の山全体がその敷地であり、斜面に は果樹園が営まれていた。近代数寄者であった井上の趣味を反映し て茶室や石塔が建ち、また山上には井上の巨大な銅像も立てられて いた。住宅は川からやや上がった、海を望むことのできる場所に建 つていた。

阿部邸は興津駅裏手の小高い山の山上にあり、南側の眺望景観が 優れている。伊藤邸は農商務省農事試験場園芸部（現在の独立行政 法人農業・食品産業技術総合研究機構果樹研究所カンキツ研究部) に隣接し、南東斜面の山の中腹に位置していた。東側には農事試験 場の農園が眼下に広がり、北西の背後の山も農事試験場の柑楟畑で ある。一方からしか出入りができず、周囲は公的機関の土地である 点、きわめて治安に配慮した敷地といってよい。景観は清見潟、三 保の松原はもちろん、東側が開けているため山越しに富士山も望む ことができ、眺望は絶好の場所である。

一方、川崎邸と大倉䄮は隣地で、ともに $6,000 \mathrm{~m}^{2}$ 程度 ${ }^{21)}$ の敷地で あった。いずれも教地は平坦で南側は小道を隔てるのみで海岸であ った。西園寺邸は同じ海岸線の清見寺下に位置し、その敷地は 1,200 $\mathrm{m}^{2}$ 程度 ${ }^{22)}$ で、当時の貴顕の別荘としては狭さが目立つ。眼前には清 見潟の先に三保の松原が浮かび、遠くには伊豆半島を望む、明るく 広い景観が開けていた。

\section{(3)建築物の姿}

住宅は、いずれも和風を基調と見なすことができるが、その具体 的な姿は多様である。

井上期の建物は、興津別荘造営以前に群馬県の磯部に所有してい た別荘を移築して本館と呼び、麻布鳥居坂本邸で天覧歌舞伎の御座 所となった建物を移筑して別館と呼んでいた。本館は井上によって 構想されたと伝えられる和洋折衰の 2 階建てで、写真と略図から推測 すると、1階が和風、2階が洋風で、伝記によると両国橋の橋杭古材 や鉋のかかっていない部材を柱として用いてあったという ${ }^{23)}$ 。別館 は平屋で、写真や伝記等から推測すると、もともと大きな和風住宅 の最奥に位置する座敷部分と思われる。

阿部邸は和風平屋であるが、建具には板ガラスが用いられ、また コンクリートのべた基礎など、建設年に照らして当時においては先 駆的な技術が見られる ${ }^{24)}$ 。

川崎邸は1888（明治21）年につくられた旅館「海水楼」を取得、 改築したものであった。正蔵の後、芳太郎の代となり、1917（大正

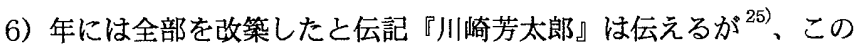
建物は建築家、山田醇の設計になるものと思われる。山田は川崎別 荘の写真を作品として著書『住宅建築の実際』に揭げているが ${ }^{26)}$ 、 ここから一部2階建ての建物であることがわかる。山田醇は日本の住
宅作家の先駆け的存在として知られているが、山田醇研究文献の年 譜によれば、彼は独自の積算法により川崎芳太郎の知遇を得て、 1917 （大正6）年11月に神戸で独立し、川崎家の仕事を引き受けて いる ${ }^{27)}$ 。この時期は伀記が伝える興津別荘の工事と合致しており、 川崎家の興津別荘は山田の独立後まもなくの仕事の可能性が高い。 伝統的な平面型よりも日射、通風等の環境的な条件が優先され、建 築家の主張が反映された初期の個人住宅であった。

大倉祁の現存する部分は、和風平屋で玄関に対して左右対称に 2 室 づつが並んでいる。座敷に達するには、両翼に囲われて玄関を入り、 直角におれて次の間、さらに直角におれて座敷、もう一度直角にお れて床の間の前と、奇妙な動線をたどる。これは普請道楽で知られ る建築主の意向によるものと思われる。

伊藤䄮は写真から判断すると、和風一部2階建てで、一部は斜面に 張り出すように建てられていた。

西園寺期は博物館明治村に移築されている ${ }^{28)}$ 。建物は数寄屋造の2 階建てで、設計監督者は則松幸十といい、この人物は住友本店臨時 建築部に属していたといわれる ${ }^{29)}$ 。主要な座敷は1、2階とも2間づ つで、道路側からは建物は全貌が見えにくく、間取りは狭い部屋を 意図的に複雑につなげ、サービス部分が多く取られている。これは 老人が一人で暮らすということから、防犯と生活上の便利さを重視 した結果と思われる。建物各所には竹が用いられ、主人の文人趣味 を反映するとともに、海側には全面にガラス戸をとり、大きく開け た視界もまた、自然のなかで隠棲をするという主人の理想を映して いるものと考光られる。

以上のように、興津に建てられた別荘は、和風を基調とすること は共通するが、主人の構想による和洋折表のもの、べた基礎など実 験的な技術を用いたもの、住宅を専門とする初期の建築家の設計に よるもの、数寄屋造の端正な構えを見せるものなど、多様な姿を見 せていた。これらは、別荘が本的に比べ主人の好みや実験珄が現れ やすいこと、近代的な生活様式や材料が和風のなかで未消化で、類 型化されていない時期に建てられていることなどが影響しているも のと思われる。

\section{(4)建築主}

建築主には当時の貴顕が見られる。試みに造営当時の爵位を見て も、公爵1 (伊藤)、侯爵1（西園寺）、伯爵2（井上、阿部）、男爵1 (川崎）と多くの華族か゚いる ${ }^{30}$ 。彼らは複数の別荘を所有しているこ とも多いが、小さな別荘地へのこの貴顕の集中は注目に值する。な かでも井上謷、川崎正蔵は近代数寄者として、西園寺公望は文人趣 味をもつ人物として知られ、彼らの美意識に照らすと、別荘地選定 にあたって、この場所が古典的名所であったことは大きな意味をも っていたものと推測される。また彼らは、かなりの高龄になってか ら興津に別荘を造営し、ここで晚年の多くを過ごした。これらの別 荘は趣味人のリトリートとしての特徴をもっていたといえる。

\section{3-2.別荘での出来事と人物のつながり}

興津において、建築主たちは同じ場所に対する指向を共有する者 たちとして考えることができる。別荘造営にあたっては建築主が自 らすすんで好きな場所を選ぶが、その場所の選定にあたって、趣味 を共有する友人や姻成関係にある人物からの紹介や伝聞は、土地を 知るきっかけや、具体的な土地の情報を得る信頼できる手段となる 


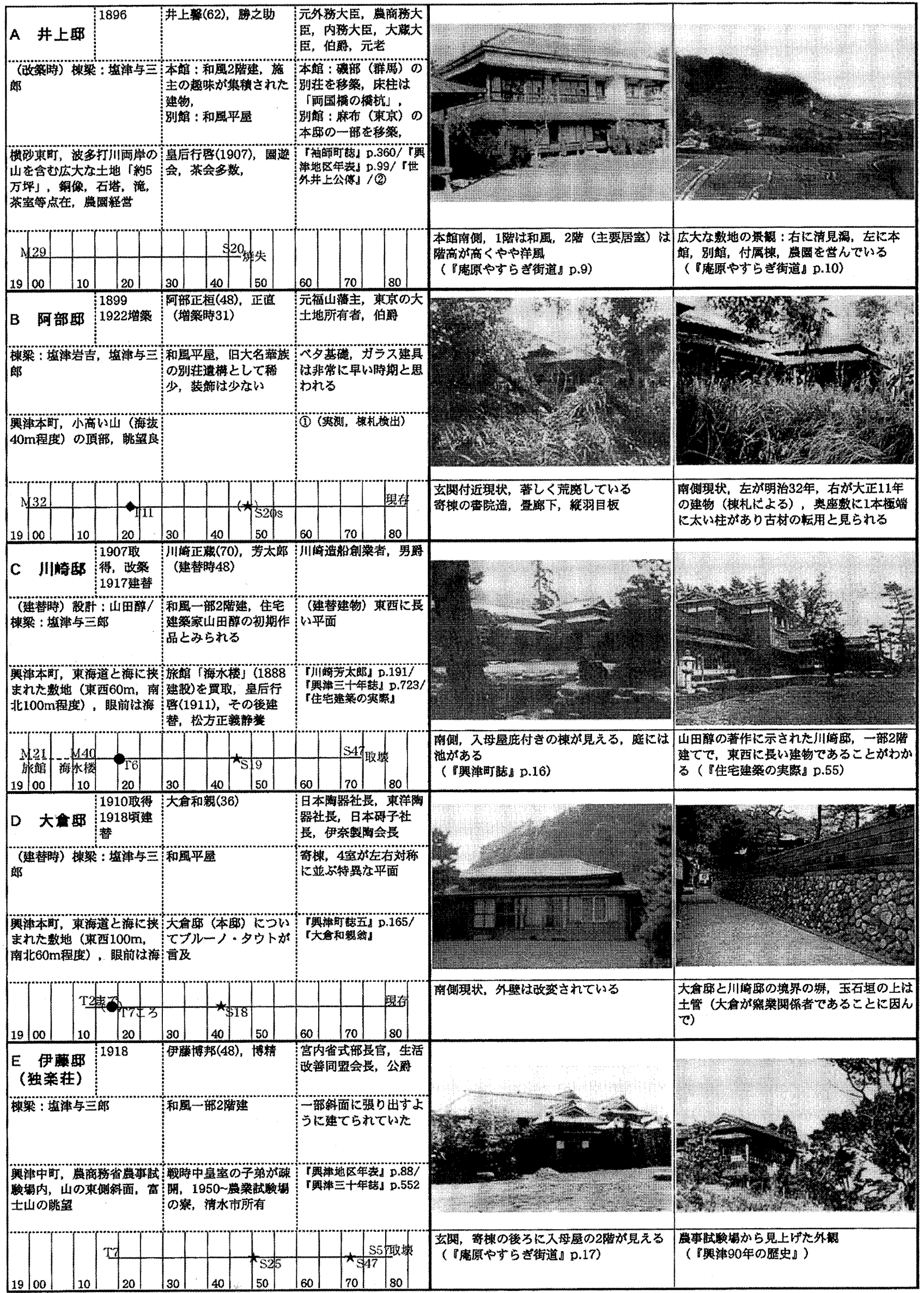




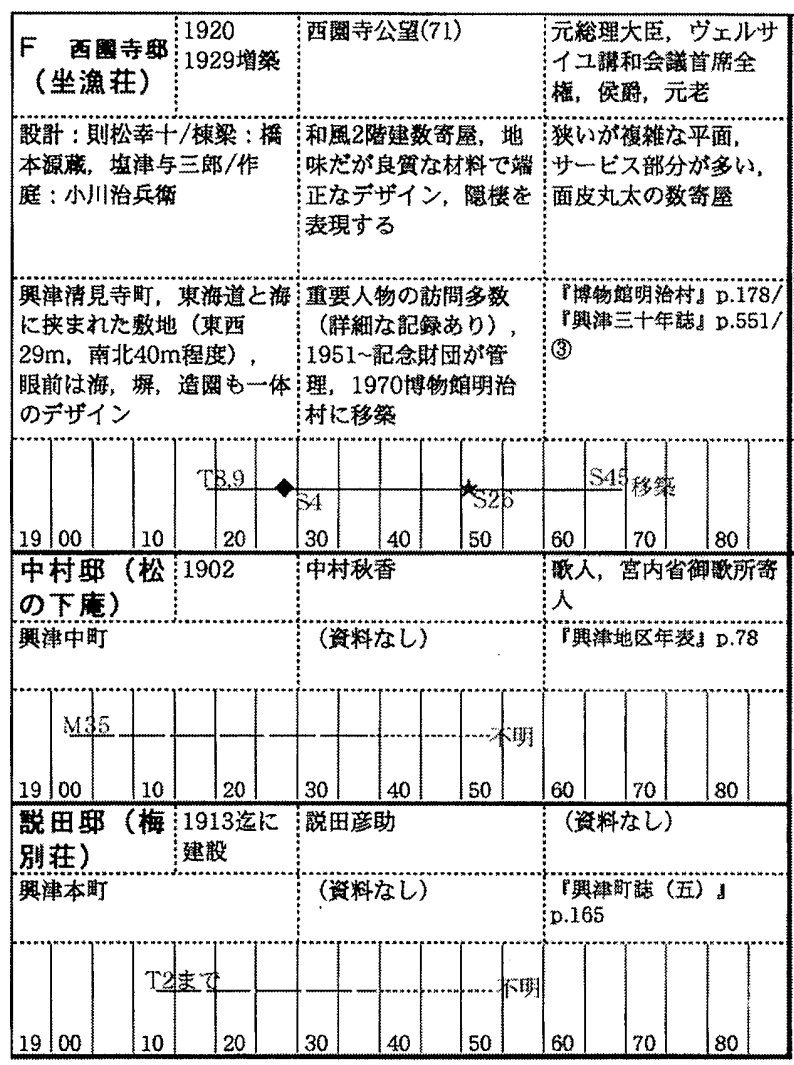

凡例

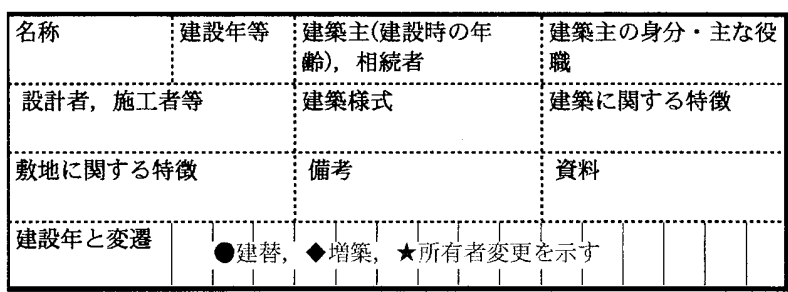

\section{资料雌に揭げた文献}

『興津町誌(五)』興津町誌編箘委員会, 1913

田中明編『興津地区年表』興津公民館内清水市合併

20 周年記念実行委員会, 1981

袖師町誌編箱委員会『袖師町誌』袖師町, 1961

『興津三十年誌』興津地区誌編集委員会, 1992

井上警侯傳記編箱會『世外井上公傳』原書房，1968

岩崎虐『川崎芳太郎』岡部五峰, 1921

『大倉和親翁』大倉和漞翁伝編集委員会, 1959

山田䤃『住宅建築の実際』新光社, 1932

博物館明治村『博物館明治村』淡交社, 1976

および本文注5(1)-(3)の既往発表

場合が多い。別荘形成要因のいわば状況証拠として別荘での出来事 と人物のつながりを検討する。

\section{(1)別䓅への行啓}

前述のように興津は皇太子の海水浴場となって以降、皇族の行辟 がたびたび行われた。行敬は従者や関係者が場所を知ることはもち ろん、高貴な人物が保養に訪れる場所として興津の名声を伝える効 果も大きかった。訪問先、滞在先は清見寺が多いが、個人の別荘で も数回行われている。井上邸には、1901（明治34）年2月に皇太子 が3泊4日で滞在し、翌月にも訪れている ${ }^{31)}$ 。1907（明治40）年3月 には皇后が沼津御用邸から訪れており ${ }^{32)}$ 、このときに描かれた略図

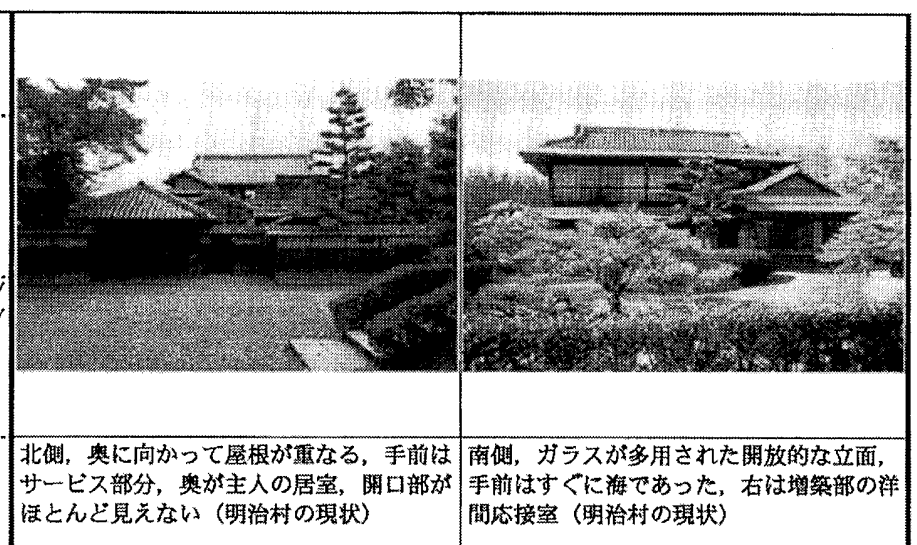

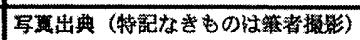

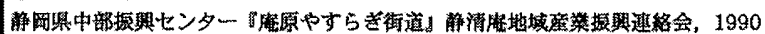

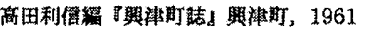

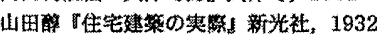

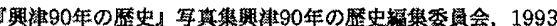

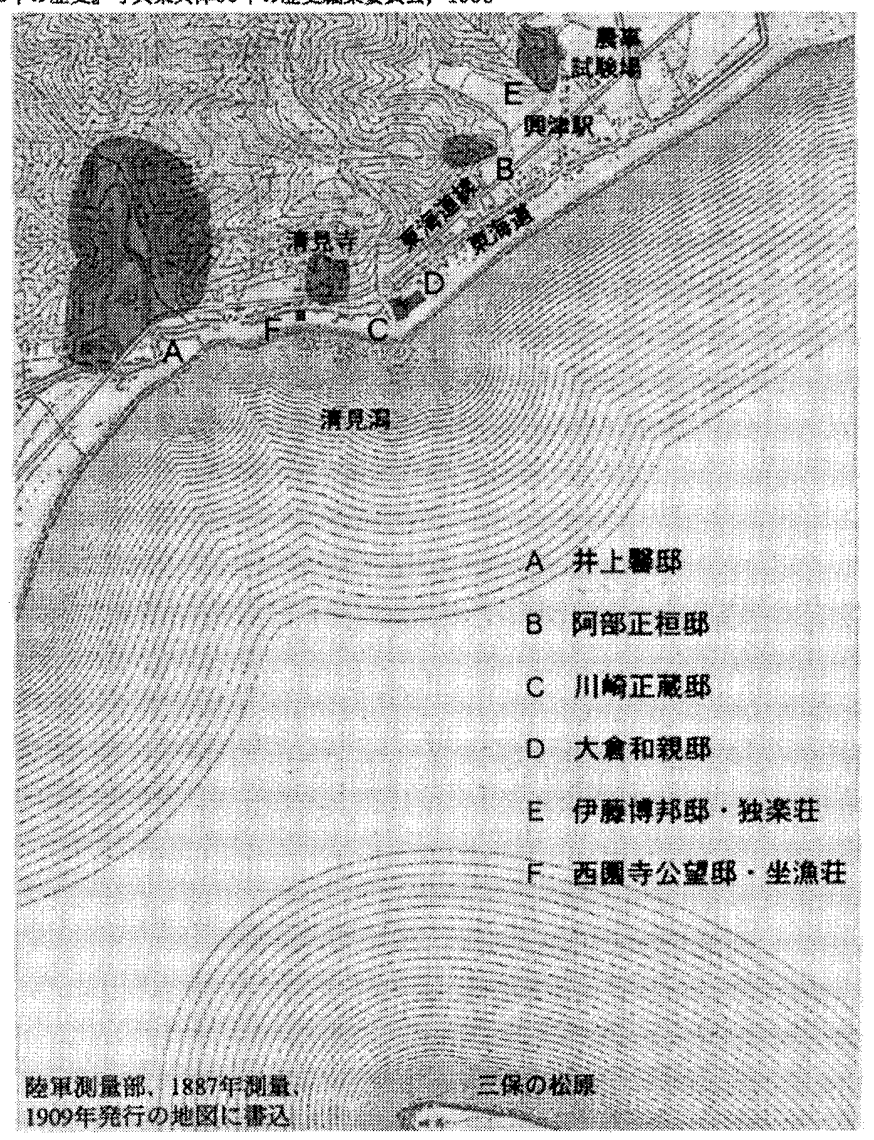

図1 興津における別荘の位置

が、井上邸の平面を知る手がかりとなっている。また、1912（明治 45）年4月には、皇太子がやはり沼津から再訪し、落語や相撲を楽 しんでいる ${ }^{33)}$ 。川崎邸にも、1911 (明治44）年に皇后が沼津から行 啓しており ${ }^{34)} 、 1917$ (大正6）年までに再度行啓があったという ${ }^{35) 。 ~}$

（2）井上邸における茶会、国遊会

井上謷は世外と号し近代数寄者として知られている。井上邸では 茶会や園遊会がたびたび開かれた。井上期に招かれた高橋篣庵の記 録によると、茶会では益田鈍翁らの数寄者仲間が集い、本館大広間 で客を出迎え、その後本館の別室や別館に移り、ここで懐石の饗応 を行い、庭園を巡って茶室魚躍庵で茶をふるまうという流れであっ 
$た^{36)}$ 。園遊会では閣僚や貴族院議員、実業家らが招かれ、1914（大 正4）年の園遊会では地元関係者を含めて招待者は約250名におよん だという ${ }^{37)}$ 。広い邸内では余興が催され、庭園を散策したり各所を 廻って建物内外を行き来した。催しが行われる時期はすべて晚秋か ら春にかけてで、この季節の交流の場を避寒地として別荘が提供し ていたことがわかる。興津における最初の別荘であった井上邱でこ のような催しが行われたことは、この土地を喧伝する効果をもって いたと思われる。

\section{(3)出身地等による人胍}

興津の別荘所有者は多くが薩長の出身地や親戚としてプライヴェ 一トなつながりを持っている。井上馨の羕嗣子、井上勝之助と伊藤 博文の養嗣子、伊藤博邦は実の兄弟で、実父は井上馨の兄である。 彼らの出身地である長州の毛利家は西園寺家ともともと関わりがあ り、西園寺公望の養埕子八郎は毛利家の出身である。伊藤邱・独楽 荘の扁額は西園寺公望の揮毫によっており、西園寺邸・坐漁荘の訪 問者名簿には伊藤博邦、井上勝之助の名がたびたび見られる。長州 に対して薩摩出身者には川崎正蔵がおり、彼は同郷の松方正義と深 い関わりをもっていた。松方は最晚年の1923（大正12）年に、川崎 邸を静盖に使っている ${ }^{38)}$ 。伊藤邸に隣接する農事試験場の技師であ った石原助熊は大久保利通の侽と伝えられる人物である ${ }^{39)}$ 。大久保 の次男の牧野伸顕は石原の従兄弟にあたるが、その西園寺との関わ りはよく知られるところである。西園寺が1917（大正6）年に「水 ロや方」より牧野峰子に宛てた書簡の送付先は「相州湯河原大倉君 別蚛」 ${ }^{40)}$ とある。この「大倉君」か゚、興津にも別荘を所有していた 大倉和親である。西園寺の1916（大正5）年の桑名鉄城宛書簡では 「相州湯河原大倉別荘」 ${ }^{41}$ より差し出されており、自身も大倉の湯河 原別荘を借りたことがわかる ${ }^{42)}$ 。湯河原での貸借者同士が数年後興 津での近所となったのである。

\section{（4）人材供給源としての農商務省農事試験場}

興津の別荘地形成における人材供給源として注目されるのは、 1902 （明治35）年に開場した農商務省農事試験場園芸部である。試 験場の設立には井上馨の影響があったと伝えられ、初代場長恩田鐵 彌は井上邱の農園管理も兼ねていた ${ }^{43)}$ 。技師であった石原助熊は西 園寺公望の避寒地選定に助言をしたといわれている ${ }^{44)}$ 。石原は坐漁 荘への訪問者名簿にもたびたび名前が見られ、後年日本女子大学の 教授となるが、この大学は西園寺と深い関わりがある。井上期の執 事を務めた柿沼昇は当初農事武験場の見習生だったというが、恩田 の薦めで井上郎に仕えるようになったという ${ }^{45)}$ 。一方、西園寺邸の 執事であった熊谷八十三は、第2代場長を勤めた後西園寺に仕えたか゚、 これは伊藤博邦の推薦によるという ${ }^{46)}$ 。柿沼のご子息によれば柿沼 の長女と熊谷の息子は結婚し、したか゚って井上蚛と西園寺邸の執事 は姻戚関係にある。西園寺の竹杖は柿沼が謹呈したといわれている 47)。

\section{4. まとめ}

別荘地としての興津の特徵は以下のようにまとめられる。まず、 別荘が形成された背景として次の点がある。

1)温暖の地であり避寒、隠棲に優れていた。

2)前近代から景勝地として歴史的、文化的に知られていた。 3)鉄道開通直後から皇太子の行啓をはじめ、著名人の来訪が相
次いだ。

興津には別荘地形成以前から古典的名所としての歴史があった。 その風土と景観があらかじめ知られていたことが、著名人の来訪を うなか゚し、都市から遠いにもかかわらず早い時期の海水浴場や別荘 地の形成につながっていったと考えられる。その上で、形成された 別荘の特徴としては次の点か゚ある。

4)別荘地としては小規模で、街が搪大しなかった。

5)別荘はいずれも和風を基調とするが、敷地、建物とも、その 規模や姿は建築主の意向を映し多様であった。

6)建築主は当時の貴顕で、その多くが交友や姻戚関係によって つながりをもっていた。

古典的風景のなかに身を置くことのできる場所として別荘地とな った興津では、この景観を改変する動きはなく、別荘地は小規模な ままであった。建筑主たちの多くが欧米の生活様式をよく知る者で ありながら、いずれも興津に和風住宅を建てたことは興味深い。別 荘の立地、形態には、建築主の趣味と暮らしぶりが反映され、例え ば広大な土地と農園を所有し園遊会や茶会を催した井上邸と、海岸 に面して小さく隠棲の構えをとった西園寺邱は対照的であった。

当時の貴顕たちが別荘地として興津を選定した理由として、1)に 加えて2)抒よび3)は重要と思われる。地理的要因に加えて、歴史的 要因は場所に蓄積された条件となり、これはいかなる土地とも代替 不可能な条件となるからである。さらに、こうした場所に別荘をも つ者として、6)のように所有者同士は気心が知れており、そうした 小さな街であるがゆえに、治安、情報の管理に優れていたといえる。 すなわち、景勝地としての前史をもち、そのような場所に対する価 値観を別荘の建築主たちが共有していたことが、興津における別荘 形成の要点であったと考察できる。

\section{謝辞}

本稿執筆にあたり、情報提供、ヒアリングにご協力いただいた、 渡辺康弘氏（静岡市文化財課）、柿沼守氏、塩津浩氏、阿部正道氏に 記して謝意を表します。また、本稿は平成18年度科学研究費補助金 （若手研究B：課題番号17760522）を受けた研究の一部である。

注

1)十代田朗、渡辺貫介、安島博幸「戦前の関東圈における別荘の立地とその 類型に関する研究」『日本建築学会計画系論文報告集』No.436、pp.79-86、 1992.6、安島博幸、十代田朗『日本別荘史ノ一ト』住まいの図書館出版局、 1991、十代田朗『関東圈における近代別荘地形成に関する史的研究』東京 工業大学学位論文、1994等

2）小沢朝江、水沼淑子「近代における皇族別荘の位置と沿革 御用期など皇 族別荘を中心とする海浜別花の研究(1)」「日本建築学会大会学術講演梗概集』 F-2分冊、pp.73-74、2000、同「葉山における皇族別荘の建築実態と生活 様式 近代における皇族期宅の建築様式と生活様式に関する研究(2)」『日本 建築学会大会学術講演梗概集』F-2分冊、pp. 351-352、2001等

3）矢ヶ崎善太郎「近代京都の東山地域における別邸群の初期形成事情」『日本 建築学会計画系論文集』No.507、pp.213-219、1998.5、同「東山大茶会 の会場となった建築・庭園の所在地と造営時期-東山大茶会に見る近代数寄 空間の研究一』日本建築学会計画系論文集』No.515、pp.243-250、 1999.1等

4）出村嘉史、川崎雅史「浄土寺・鹿ヶ谷・若王子における近代以降の景域形 成に関する研究」『土木学会論文集』779巻4-66号、pp.95-104、2005等

5) (1)「興津の地域環境形成に関する史的研究その1 阿部正桓別邸について」 
『日本建築学会大会学術講演梗概集』F-2分冊、pp.373-374、1998、 (2)「別荘地・興津と井上警の別荘 興津の地域環境形成に関する史的研究そ の3」阳本建築学会大会学術講演梗概集』F-2分冊、pp.361-362、1999、 (3)「西園寺公望別荘・坐漁荘における建設の経緯と空間構成 興津の地域環 境形成に関する史的研究その4」『日本建築学会東海支部研究報告集』38号、 pp.837-840、2000、(4)『近代和風住宅を通した景勝地の形成に関する史的 研究』芝浦工業大学学位論文、2000。本稿は(1)(2)(3)よび(4)の興津に関す る部分を総合的に検証し直し、新たな知見を加えて書き下ろしたものである。 6) 戦後には、新幹線、東名高速道路、国道1号線バイパスがこの地区内を通り、 それまでの景観は一変した。とりわけ、国道1号バイパスの高架橋は海上を 通り、興津地区からはほとんど海が見えなくなってしまった。また、清水港 の拢張にともなって海上に埠頭が建設され、清見鼬は失われた。

7) 近代初期までの認識では、田子の浦は興津から吉原付近の海岸と考えられ る。例えば貝原益軒の「東路記』(1684（貞享2）年）では「清見寺の客殿 に雪舟の絵あり。清見寺の堂の前、絶景なり。興津、清見寺あたりの浜、清 見湶也。興津と江尻の間に田子の浦有。」(板坂耀子校注『東路記、己已紀行、 西遊記』岩波書店、1991、p.12）とある。また、『東海道名所図絵』では、

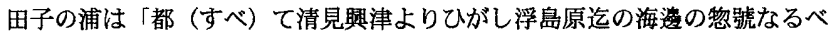
し」（櫻井庄吉『日本図絵全集：東海道名所図絵』下巻、日本随筆大成刊行 会、1928、p.591（秋里箁島「東海道名所図絵」復刻)）とある。また、江 戸城障壁画下絵の書込から、当時の絵師が興津の海を田子の浦とみなしてい たことがわかる (注8参照)。

8）東京国立博物館 『江戸城障壁画の下絵』第一法規出版、p.17、1989、拙 稿「伝雪舟筆『富士三保清見寺図』における富士山の表現にもとづく興津の 場所性に関する考察」『常葉学園大学研究紀要・教育学部』26号、pp.173185, 2006

9）長谷川成一『失われた固観 名所が語る江戸時代』吉川弘文館、1996、 pp.13-22によれば、大淀三千風の本朝十二景（1690（元禄3）年）では、 全国12力所の景勝地のうち、田子の浦を第1位に挙げている。古川古松軒の 『東遊襍記』（1788（天明8）年）でも「富士山・田子の浦、清見ケ関、美 穂ケ崎」を第1位に挙げている。

10）歴代の朝鮮通信使による記録の他に、清見寺総合資料調查報告書 : 静岡 県文化財調查報告書』49号、静岡県教育委員会、1997によれば清見寺には

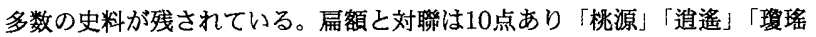
世界」「東海名区」と場所の美しさを隻め称えたものが目立つ。

11）宮内仃『明治天皇紀』第七、吉川弘文館、1972、p.406によれば皇太子と なるのは明治 22 年 11 月である。

12）興津が皇太子の海水浴場として選ばれた経緯は不明である。1889（明治 22）年発行の『興津海水浴場趣意書』によれば、興津の選定には東宮侍医、 原田豊が関わっていたことがわかる。原田䅱について前揭『明治天皇記』て は1885（明治18）年に4等侍医となり（同書第六p.525）、「皇太子の择診に 尃従」(同書第八p.433) とある。

13）『興津町誌』下巻、興津町公民館、1950、p.161

14）前揭『興津町誌』下巻、pp.160-164、田中明編『興津地区年表』興津公 民館内清水市合併 20 周年記念実行委員会、1981、pp.54-98、『一碧楼水口 屋展』清水港湾博物館、1995、pp.7-10

15）前揭『一碧楼水口屋展』

16）立命館大学西園寺公望伝編纂委員会『西園寺公望伝』別巻 $1 、 2 、$ 岩波書店、 1997に揭載された書簡によると、西園寺は坐漁䓅建設前の1916（大正5） 年から1918（大正7）年にかけて4回にわたり滞在している。

17)「坐漁荘秘聞」『季刊清水 特集坐漁荘』29号、戸田書店、1992、p.10 18)このほかに興津には、著名人の別荘ではないが、近代和風住宅を手がけた 建築家の作品として山田醇の設計になる住宅 2 件出現存する。これについて は、拙稿「興津に㧍ける山田醇設計の住宅について〈W氏期〉興津の地域 環境形成に関する史的研究その2-1」ならびに「同〈A氏邱（旧五島別邸）〉 同2-2」『日本建築学会関東支部研究報告集』69号、pp.577-584、1999を 参照。

19）井上馨侯傳記編算會『世外井上公傳』第5巻、原書房、1968（1933-34版 の復刻)、p.606では、「二十九年の頃」、袖師町誌編箘委員会『袖師町誌』 袖師町、1961、p.360では「明治29年1月」、北野彗『興津と元老』松永益 発行、1966には明治28年に建設を始め、29年1月に竣工とある。また『世 外井上公傅』には次の狂歌が紹介されている。「明治二十九年二月四日興津 を出立して東京の家に歸りけるとき世磨を避くるため、人に逢わぬため、両
三日滞在して再び興津におもむきける 我家に彗るも人の目にかくれ愁にも あらで世をいとふ身は」(p.568)ここから井上馨が興津に別荘を造営した のは1895（明治28）年か96（同29）年と判断される。

20）前揭『興津と元老』p.15および『東海道薩垂岾：東と西の出会う道』静岡 国道工事事務所、1994、p.65。関係者の手元に当時の地籍図が残されてお り、その全部の範囲が井上期の敷地だとすれば、現在の地図と比べてこれら の広さとほぼ合致する。

21）旧敷地の現状からの推測値による。

22) 跡地に立つ「坐漁荘址」の碑文によると1,255.96 $\mathrm{m}$ とある。この活か史料

によっていくつかの説がある。

23）前揭『世外井上公德』第5巻、p.591

24）1998年3月に行った実測調查によって確認した。

25）岩崎虔『川崎芳太郎』岡部五峰発行、1921、p.191

26）山田醇『住宅建築の実際』新光社、1932、口絵。なお注18のとおり、山 田はこの約 20 年後の円熟期に興津で住宅 2 件を手がけることになる。

27）世田谷住宅史研究会（内田青蔵氏担当筒所）『世田谷の住居 その歴史と

アメニティ調查研究報告書』世田谷区建築部、1991、p.114

28）1970（昭和45）年6月に解体され、1971（昭和46）年3月に博物館明治村

に移築された。跡地には2004（平成16）年に複製が建てられた。

29）明治村蔵の棟札には次のように記されている。設計監督者 則松幸十、工事 関係者 橋本源蔵、大工 塩津與三郎。塩津家には別の住宅の図面が所藏され、 そこに「則松」「日高」の印がある。「日高」は住友本店蹿時建築部の日高㭌 とみられ、則松は日高の部下と考えられる。

30）後には西園寺は公爵、井上は侯爵となる。

31）『井上馨関係文書目録』国立国会図書館参考書誌部、1975、p.406

32）前揭『世外井上公傅』第5巻、p. 240

33）前揭『世外井上公傅』第5巻、p. $248 、 520$

34) 山本實彦『川崎正藏』吉松定志発行、1918、p.161

35）前揭『川崎芳太郎』p.191

36）高橋箒庵著、熊倉功夫 - 原田茂弘校注『東都茶会記』第2巻、淡交社、 1989、p. 157

37) 高橋義雄 『萬象録』巻3、思文閣出版、1987、p.142

38) 前揭『興津町誌』下巻、p.16および前揭『興津と元老』p.54

39）前揭『季刊清水 特集坐漁荘』 29 号、p.43

40) 前揭『西園寺公望伝』別巻 $1 、$ p. 254

41）前揭『西園寺公望伝』別巻1、p.83

42）湯河原町立図書館が調查した神奈川県公文書館の土地台艮によれば、湯河 原の大倉の別茌は 1910 (明治43）年3月 22 日に登記されている。『大倉和親 翁』大倉和視湇伝編集委員会、1959、p.287には、「大倉さんの別茌めぐり」 と題して、興津、大倉の父孫兵衛の熱海の別荘、湯河原と巡る話が語られて いる。

43）前揭『世外井上公傳』第5巻、p.610

44）『西園寺公爵警備浻革史』静岡県警察部、1941、p.5によれば、注16の滞 在の前に、西園寺の秘書であった川村純藏が、知人の石原助熊に相談し、石 原が水口屋を薦めたとある。

45）柿沼昇『井上侯と西園寺公の逸話』清水寿大学、1972、p.201

46) 前揭『興津と元老』p.130

47）前揭『井上侯と西園寺公の逸話』p.159

（2006年10月 4 日原稿受理，2006年12月18日採用決定） 